\title{
EFFECT OF SOLUTION TREATMENT TEMPERATURE ON THE MICROSTRUCTURE AND TENSILE PROPERTIES OF P/M (HIP) PROCESSED SUPERALLOY INCONEL 718
}

\author{
G. Appa Rao ${ }^{1}$, Mahendra Kumar ${ }^{1}$, M. Srinivas ${ }^{1}$ and D. S. Sarma ${ }^{2}$ \\ ${ }^{1}$ Defence Metallurgical Research Laboratory \\ Kanchanbagh (PO), Hyderabad - 500 058, India \\ ${ }^{2}$ Department of Metallurgical Engineering, Institute of Technology \\ Banaras Hindu University, Varanasi - 221005 , India
}

\begin{abstract}
Inert gas atomized superalloy Inconel 718 powder was hot isostatically processed (HIPed) at $1200{ }^{\circ} \mathrm{C} / 120 \mathrm{MPa} / 3 \mathrm{~h}$. This material was then subjected to a standard heat treatment schedule adopted for wrought IN $718\left(955^{\circ} \mathrm{C} / 1 \mathrm{~h}\right.$. / water quenching and two - step ageing at $720{ }^{\circ} \mathrm{C} / 8 \mathrm{~h}$. / furnace cooling to $620^{\circ} \mathrm{C} / 8 \mathrm{~h}$. / followed by air cooling to room temperature), which showed substantial improvement in strength but a drastic decrease in ductility. Since, the solution treatment temperature has a significant influence on microstructure development, the HIPed compacts were subjected to various solution treatment temperatures between 850 and $1270{ }^{\circ} \mathrm{C}$, while the same ageing treatment was retained. The microstructure of the compacts in the as - HIPed, solution treated and aged conditions was studied in detail. The tensile properties of these samples were evaluated at room temperature and at $650{ }^{\circ} \mathrm{C}$. The microstructure corresponding to the solution treatment temperature of $1270{ }^{\circ} \mathrm{C}$, showed incipient melting at the particle boundaries leading to enhanced bonding across the particles and resulting in a considerable improvement of ductility.
\end{abstract}




\section{Introduction}

Superalloy 718 exhibits good strength, adequate resistance to low cycle fatigue and oxidation resistance up to $650^{\circ} \mathrm{C}$. Hence, it is extensively used in aircraft, aerospace, nuclear and petrochemical industries $[1,2]$. Though processing of this alloy is generally carried out through ingot metallurgy route, there are problems associated with microsegregation of alloying elements $[3,4]$.

Use of powder metallurgy processing techniques result in improved alloy homogeneity and microstructure, which ultimately improve tensile and fatigue properties [5]. Alloy 718 powder is usually consolidated either by sintering under atmospheric pressure or hot extrusion. The compacted material is further isothermally forged to required shapes. The mechanical properties of these are better than their forged counterparts made through ingot metallurgy [6]. Osprey forming and powder injection moulding are two other techniques used for making near net shape IN 718 components [7, 8]. However, the residual porosity present in components produced by these techniques is a major drawback for critical applications. The above limitation can be overcome by a single step HIP technique, where near net shaped components with near theoretical density and isotropic properties are achieved [9]. Usually P/M (HIP) processed nickel base superalloys have been associated with inferior ductility compared to wrought material due to the presence of prior particle boundaries (PPBs). Improvement in ductility can be achieved by an additional step of thermomechanical working [10], however, the near net shape advantage of HIP route is lost. In this study, efforts have been made to improve the ductility of HIPed alloy 718 by modifying the heat treatment schedule to retain the advantage of near net shape.

\section{Experimental Procedure}

The starting material for this study was argon atomized prealloyed IN 718 powder (supplied by Osprey Metals Ltd; U.K.), the morphology of particles is shown in Fig.1. The as received powder was chemically analysed for its composition. The powder particle shape, size distribution, mean particle size, apparent density, tap density and flow rate were measured as per the standard procedures [11]. The powder was encapsulated by filling into stainless steel capsules of suitable size and hot degassed at $800^{\circ} \mathrm{C}$ for 8 hours and then crimp - sealed under a dynamic vacuum of $6.5 \times 10^{-4} \mathrm{~Pa}$. The encapsulated powder was consolidated in an ASEA QUINTUS QIH - 32 hot isostatic press (HIP) at $1200^{\circ} \mathrm{C}$ under a pressure of $120 \mathrm{MPa}$ for 3 hours. The HIPed material was initially heat treated at $955^{\circ} \mathrm{C}$ for $1 \mathrm{~h}$. / water quenched (WQ). This was followed by a two - step ageing treatment consisting of $720{ }^{\circ} \mathrm{C} / 8 \mathrm{~h}$. / furnace cooling (FC) to $620^{\circ} \mathrm{C}$ and holding at $620^{\circ} \mathrm{C}$ for $8 \mathrm{~h}$. followed by air cooling (AC) to room temperature. Another set of compacts was heat treated at various solution treatment temperatures between $850^{\circ} \mathrm{C}$ and $1270^{\circ} \mathrm{C}$ for 1 hour, while the ageing treatment was kept same. Optical metallography, scanning electron microscopy and electron probe micro analysis were carried out on these samples. Transmission electron microscopy was carried out on the thin foils prepared from the selected samples. Tensile specimens $(4.06 \mathrm{~mm}$ gauge diameter and $25.4 \mathrm{~mm}$ of gauge length) were prepared from the various compacts. Tensile tests were carried

out at room temperature and at $650^{\circ} \mathrm{C}$ at a strain rate of $6.56 \times 10^{-4} \mathrm{~s}^{-1}$. The fractured surfaces of the specimens were examined under SEM to study the fracture characteristics. 


\section{Results and Discussion}

\section{As - HIPed Material}

The microstructure of as - HIPed compact (Fig.2.a) shows complete absence of porosity and the presence of fine particles, which could be carbides or oxides. The microstructure (Fig.2.b) further reveals annealing twins, prior particle boundaries (PPBs). Presence of second phase particles $(\sim 1$ to $2 \mu \mathrm{m})$ can also be seen along the particle boundaries. It was confirmed by EPMA studies, that these particles were MC type carbides enriched with $\mathrm{Nb}$ and $\mathrm{Ti}$, while the PPBs had Ti and Al rich oxide films [12]. Formation of these films can be attributed to the high oxygen content $(275 \mathrm{ppm})$ of prealloyed powder as indicated in Table - I. The PPBs did not allow the powder particles to undertake deformation during HIPing, resulting in retainment of spherical shape of the powder particles in the grain structure. The microstructure analysis further revealed that grain size is varying between 5 and $50 \mu \mathrm{m}$, with an average value at $25 \mu \mathrm{m}$. The variation of grain size can be attributed to the wide particle size distribution of the alloy powder as given in Table - II.

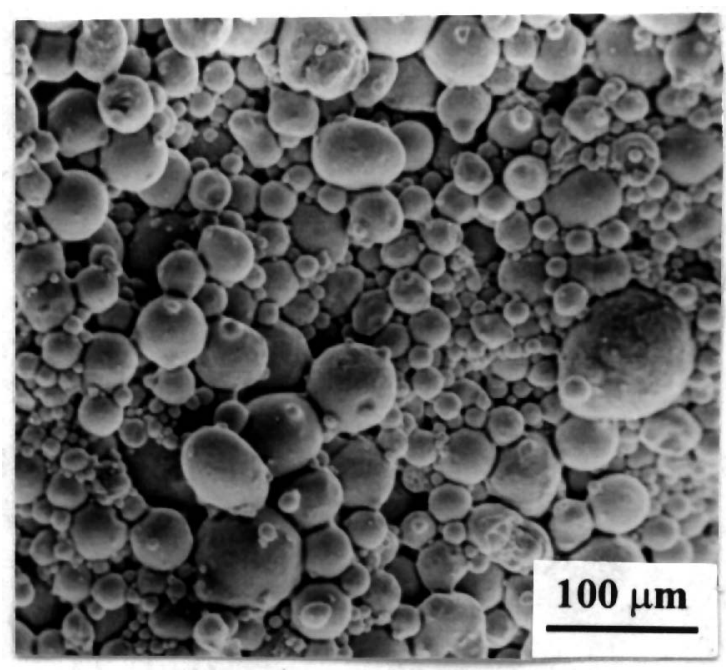

Figure 1: Morphology of argon atomized IN 718 alloy powder particles.

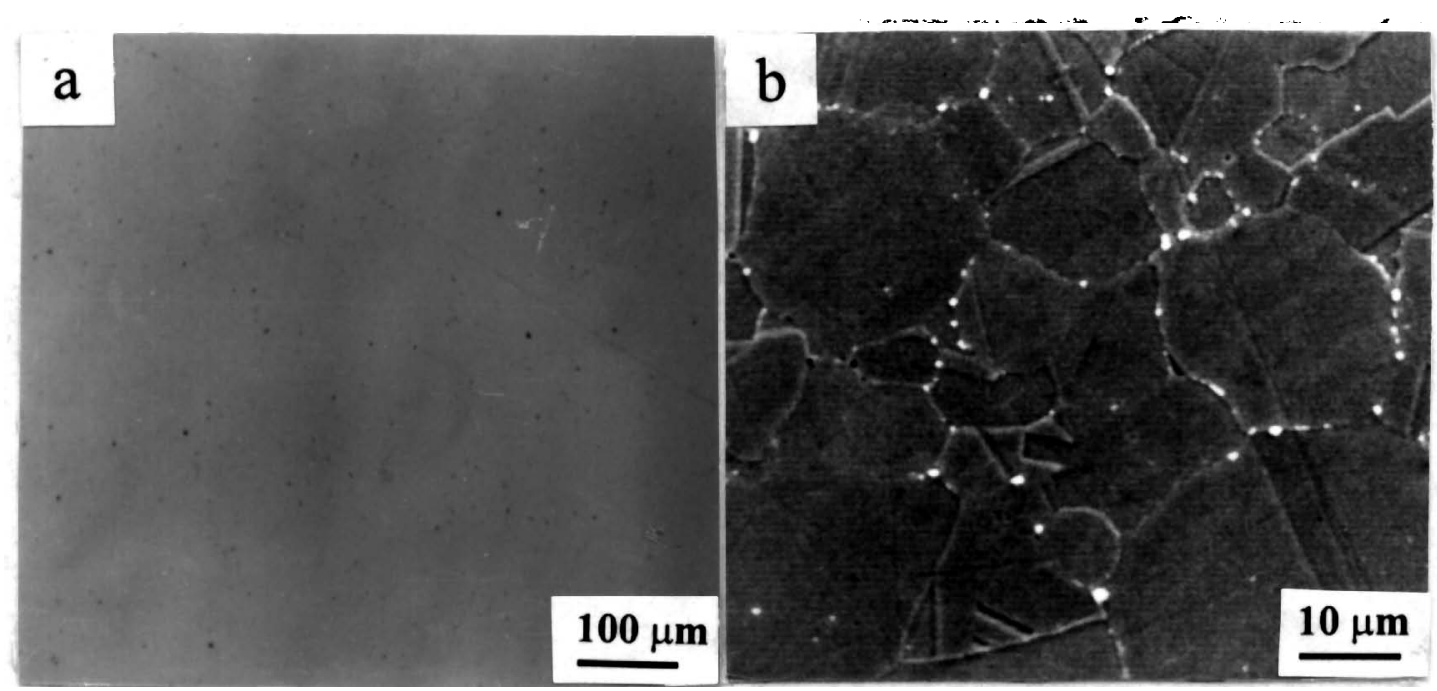

Figure 2: Microstructure of IN 718 compact HIPed at $1200^{\circ} \mathrm{C} / 120 \mathrm{MPa} / 3 \mathrm{~h}$. (a) As - polished condition (b) Etched condition 
Table I Chemical Composition of Argon Atomized IN 718 Alloy Powder

Elements (wt. \%)

\begin{tabular}{|c|c|c|c|c|c|c|c|c|}
\hline $\mathrm{Cr}$ & $\mathrm{Fe}$ & $\mathrm{Nb}$ & $\mathrm{Mo}$ & $\mathrm{Al}$ & $\mathrm{Ti}$ & $\mathrm{C}$ & $\mathrm{Ni}$ & $\mathrm{O}$ \\
\hline 19.6 & 18.9 & 4.7 & 3.1 & 0.8 & 0.5 & 0.03 & Balance & $275 \mathrm{ppm}$ \\
\hline
\end{tabular}

Table II Physical Properties of Argon Atomized IN 718 Alloy Powder

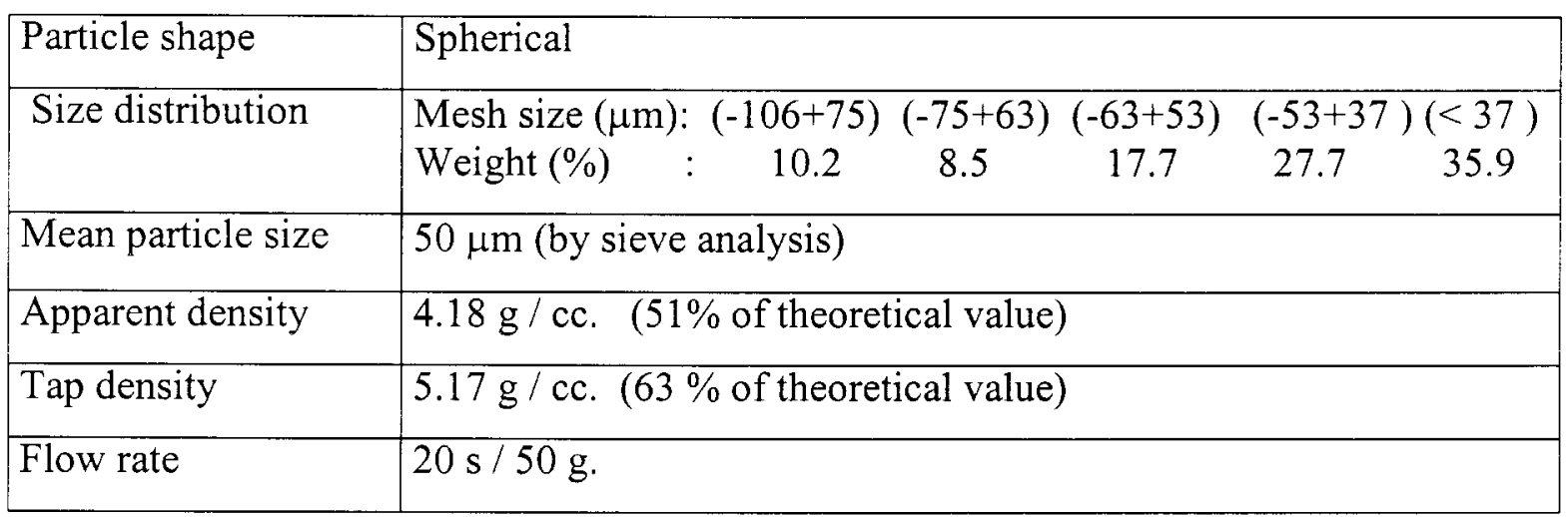

The room temperature tensile properties of the as - HIPed samples showed tensile strength and ductility that meets the requirement as per the AMS 5662G for wrought IN 718 alloy (Table - III). On the other hand, the yield strength was found to be marginally lower than the specified value and could be attributed to the low volume fraction of $\gamma^{\prime \prime}$ and $\gamma^{\prime}$ precipitates in the matrix associated with a lack of adequate ageing treatment after HIPing. Due to the low volume fraction of these precipitates, cross - slip becomes more predominant which resulted in greater ductility and lowered yield strength. The tensile properties corresponding to test temperature $650{ }^{\circ} \mathrm{C}$ showed strength values within the AMS 5596 range with a drastic reduction in ductility. The deterioration of ductility can be attributed to the presence of PPB networks [13]. The SEM fractograph of the sample tensile tested at room temperature showed particle boundaries (Fig.3.a), however, the sample exhibited $19.4 \%$ elongation and is comparable to that of wrought material. The higher ductility associated with particle boundary decohesion can be due to the tortuous crack path along the boundaries which could delay the fracture. The samples tested at $650^{\circ} \mathrm{C}$ revealed a mixed interparticle - intergranular mode of fracture (Fig. $3 \mathrm{~b}$ ). The presence of fine dimples within the grains suggested that formation of very tiny voids near the matrix - precipitate interface.

Table III Tensile Properties of As - HIPed IN 718 Alloy

\begin{tabular}{|c|c|l|c|}
\hline Test temperature & $0.2 \% \mathrm{YS}(\mathrm{MPa})$ & UTS(MPa) & $\% \mathrm{EL}$ \\
\hline $25^{\circ} \mathrm{C}$ & 993 & 1334 & 19.4 \\
\hline AMS $5662 \mathrm{G} *$ & $1035-1167$ & $1275-1400$ & $12-21$ \\
\hline $650^{\circ} \mathrm{C}$ & 907 & 1028 & 3.0 \\
\hline AMS $5596^{*}$ & $860-1000$ & $1000-1200$ & $12-19$ \\
\hline
\end{tabular}

* Property requirement for wrought IN 718 alloy after ageing treatment. 


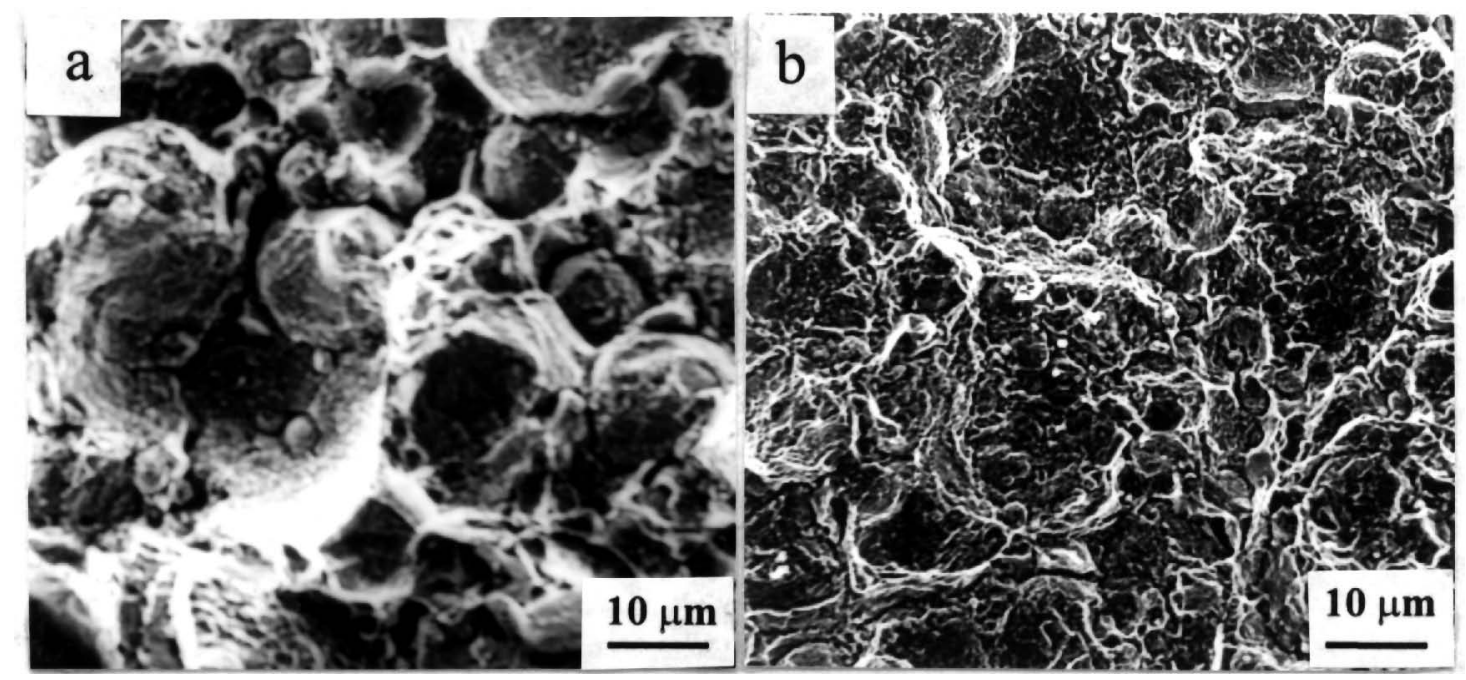

Figure 3: Fractographs of as - HIPed IN 718 alloy samples

(a) Tensile tested at room temperature (b) Tensile tested at $650^{\circ} \mathrm{C}$.

\section{Material subjected to Standard Heat Treatment Schedule}

The microstructure of the HIPed compacts subjected to standard heat treatment schedule $\left(955^{\circ} \mathrm{C} / 1 \mathrm{~h}\right.$. $/ \mathrm{WQ}$. and two-step ageing at $720^{\circ} \mathrm{C} / 8 \mathrm{~h}$. $/ \mathrm{FC}$. to $620^{\circ} \mathrm{C} / 8 \mathrm{~h} . / \mathrm{AC}$. to room temperature) analyzed under TEM show that the major strengthening phases $\gamma^{\prime \prime}$ and $\gamma$ ' were present in the matrix [Fig.4. (a) \& (b)]. In addition, the microstructure shows decoration of $\mathrm{MC}$ carbides (enriched with $\mathrm{Nb} \& \mathrm{Ti}$ ) at the particle boundaries (Fig.4.c). The formation of such carbides is possible during slow cooling stage of HIPing. The microstructure further reveals $\delta-\mathrm{Ni}_{3} \mathrm{Nb}$ precipitates with plate-like morphology at the particle boundaries (Fig.4.d). Such precipitation takes place during solution treatment at $955^{\circ} \mathrm{C}$, where $\gamma+\delta$ equilibrium exists [14].

The tensile properties of the compacts subjected to standard heat treatment schedule, evaluated at room temperature showed that the yield strength increases considerably and is above the specified range as per the AMS 5662G for wrought material (Table - IV). While the tensile strength is within the specified range, the ductility, however, was considerably lowered. The improvement in strength could be attributed to the precipitation of $\gamma^{\prime \prime}$ and $\gamma$ ' phases during ageing. When compared to the as - HIPed material the strength is higher and the ductility is very much decreased in the heat treated condition. This could be due to the formation of more $\gamma^{\prime \prime}$ and $\gamma^{\prime}$ precipitates during ageing leading to cutting of particles (planar-slip) by dislocations. In addition, preferential precipitation of carbides at the particle boundaries during ageing could be another reason for lower ductility. The samples tested at $650{ }^{\circ} \mathrm{C}$ show that strength values are within the specified range as per the AMS 5596, but the ductility was extremely poor. Deterioration of ductility at elevated temperature can be attributed to the persistence of the PPB networks in the material [15]. The fractograph of room temperature tensile tested sample shows particle boundaries (Fig.5.a), suggesting interparticle failure. The sample tensile tested at $650{ }^{\circ} \mathrm{C}$ reveals fine dimples in the interior of coarser grains and fine particle boundaries (Fig.5.b), indicating that formation of voids at the matrix - precipitate interface and decohesion of fine particle boundaries resulting in prematured fracture at elevated temperature. 

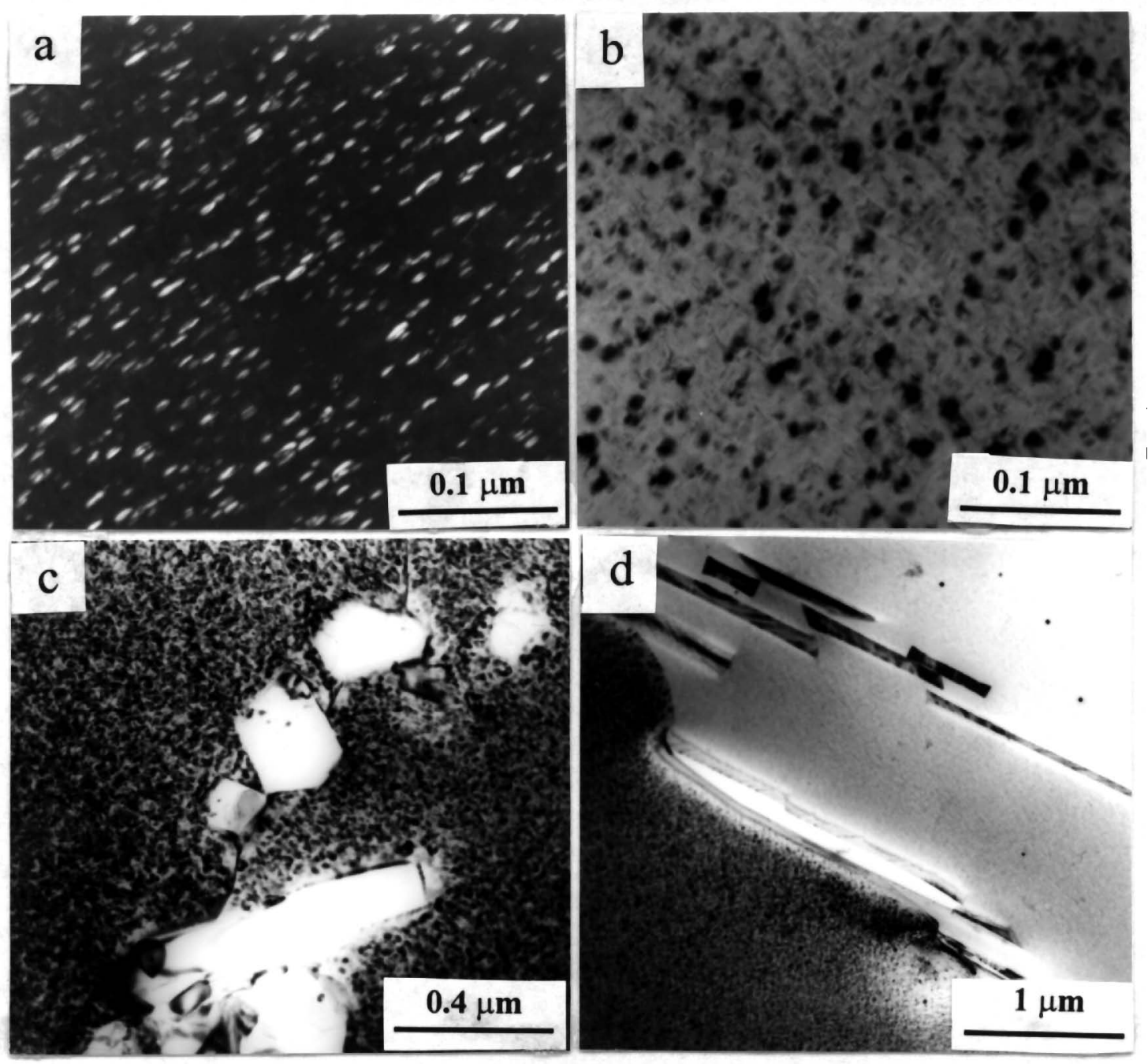

Figure 4: TEM micrographs of HIPed IN 718 alloy heat treated at $955^{\circ} \mathrm{C} / 1 \mathrm{~h}$. WQ and ageing at $720^{\circ} \mathrm{C} / 8 \mathrm{~h}$. FC.to $620^{\circ} \mathrm{C} / 8 \mathrm{~h}$. $/ \mathrm{AC}$.

(a) $\gamma$ " strengthening precipitates in the matrix

(b) $\gamma$ ' strengthening precipitates in the matrix

(c) Decoration of $\mathrm{MC}(\mathrm{Nb} \& \mathrm{Ti}$ rich) carbides at the particle boundary

(d) $\delta-\mathrm{Ni}_{3} \mathrm{Nb}$ phase at the particle boundary.

Table IV Tensile Properties of HIP + Heat Treated IN 718 Alloy

\begin{tabular}{|c|l|l|c|}
\hline Test temperature & $0.2 \%$ YS (MPa) & UTS(MPa) & $\%$ EL \\
\hline $25^{\circ} \mathrm{C}$ & 1212 & 1399 & 8.5 \\
\hline AMS $5662 \mathrm{G}^{*}$ & $1035-1167$ & $1275-1400$ & $12-21$ \\
\hline $650^{\circ} \mathrm{C}$ & 1009 & 1132 & 2.7 \\
\hline AMS $5596^{*}$ & $860-1000$ & $1000-1200$ & $12-19$ \\
\hline
\end{tabular}

* Property requirement for wrought IN 718 alloy after ageing treatment. 


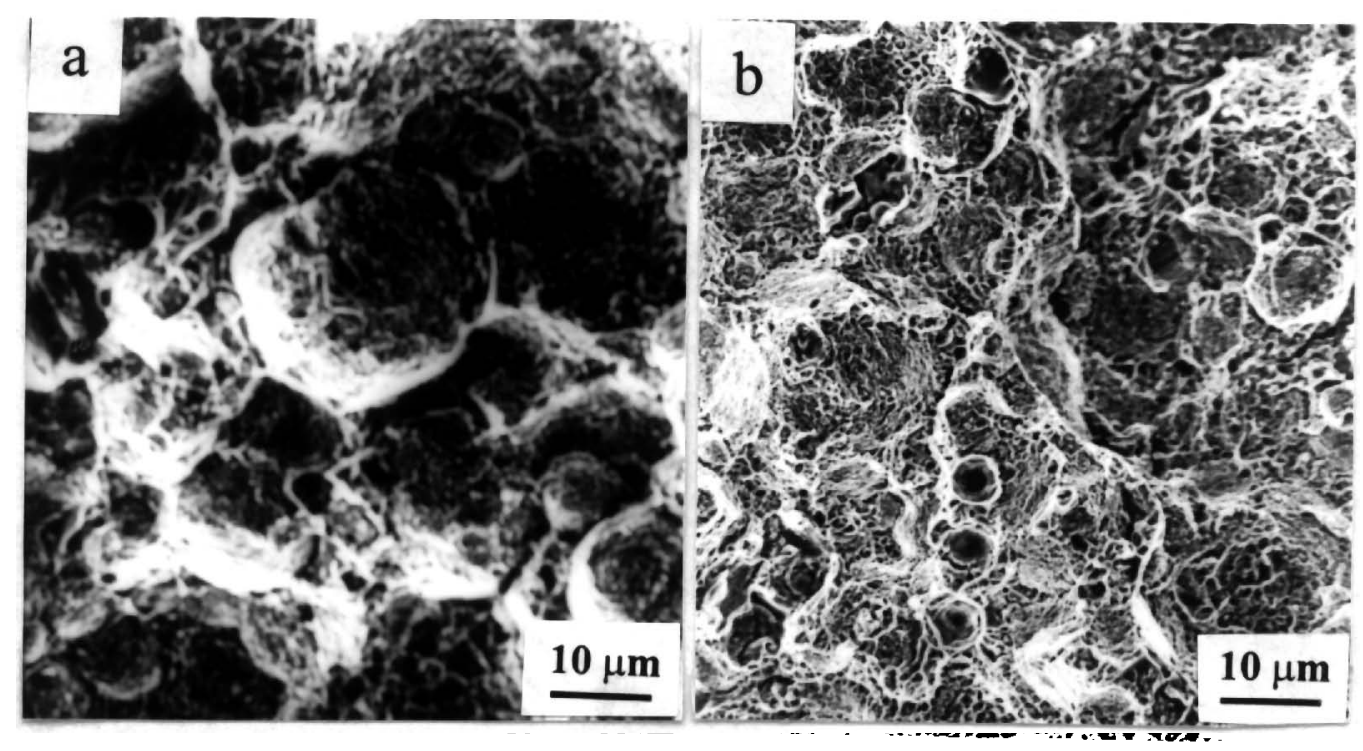

Figure 5: Fractographs of HIPed IN 718 alloy heat treated as per the standard schedule (a) Tensile tested at room temperature (b) Tensile tested at $650^{\circ} \mathrm{C}$.

\section{Optimization of Solution Treatment Temperature}

Since the ductility values were poor in the compacts subjected to standard heat treatment schedule, the compacts were solution treated at varying temperatures $\left(850-1270{ }^{\circ} \mathrm{C}\right)$, which was expected to result in better inter diffusion of elements, and associated changes in microstructure. When solution treated at $850^{\circ} \mathrm{C}$ precipitation of orthorhombic $\delta-\mathrm{Ni}_{3} \mathrm{Nb}$ phase with globular morphology was found to occur at the particle boundaries (Fig.6.a). Increasing the temperature to $955^{\circ} \mathrm{C}$ resulted in profuse precipitation of $\delta$ - phase in the matrix and along the grain boundaries with globular and plate-like morphologies (Fig.6.b). Further increasing solution treatment temperature to $1050^{\circ} \mathrm{C}$ led to dissolution of $\delta$-phase (Fig.6.c), as it is above the $\delta$ solvus [16]. Increasing the solution treatment temperature to $1150{ }^{\circ} \mathrm{C}$, resulted in dissolution of primary ( $\mathrm{Nb} \& \mathrm{Ti}$ rich $\mathrm{MC}$ ) carbides, decrease in volume fraction of second phase particles (Fig.6.d). While such carbide dissolution in wrought alloy result in excessive grain growth [17], the presence of PPBs in HIP processed alloy restricted the grain growth. Further increase in solution treatment temperature to $1250^{\circ} \mathrm{C}$, caused incipient melting, at the particle boundary triple points, though no change was observed in the PPB networks and grain size (Fig.6.e). Still further increase in solution treatment temperature to $1270{ }^{\circ} \mathrm{C}$ resulted in appreciable melting at the particle boundaries. Which caused disruption of boundary films resulting in particle boundary migration and enhanced bonding across the particles. The initial spherical shape of coarse particles changed to irregular shape (Fig.6.f). A similar observation was reported on HIPed superalloy $713 \mathrm{LC}$ by Wallace et al. [18]. The finer particles however retained their spherical shape, due to lower volume fraction of liquid phase formed on the finer particle boundaries compared to that of coarser particles. When compared to as - HIPed compact, with grain size of $25 \mu \mathrm{m}$, the material subjected to solution treatment at $1270{ }^{\circ} \mathrm{C}$ showed a slight grain coarsening with an average grain size of $35 \mu \mathrm{m}$. 


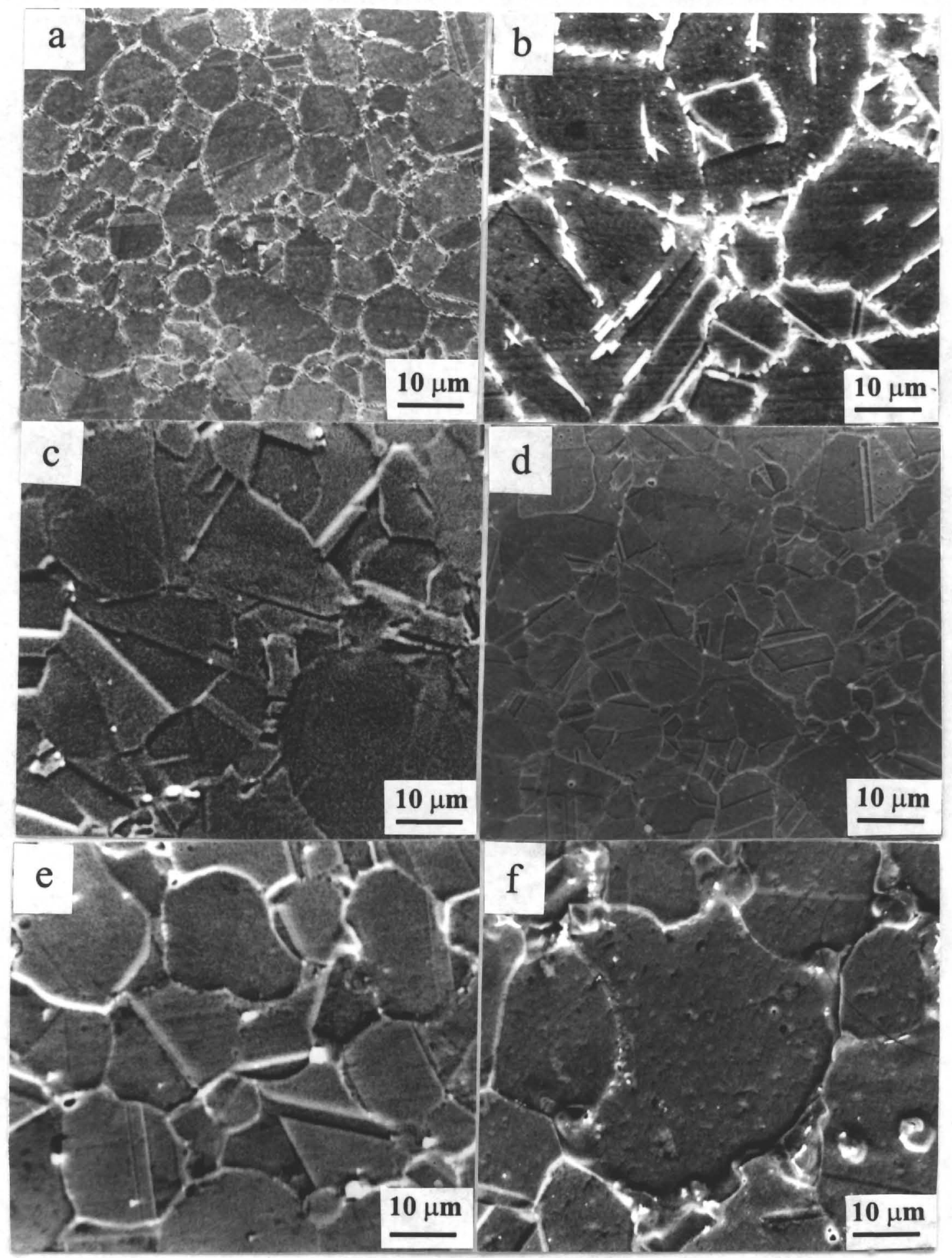

Figure 6: Microstructure of HIPed IN 718 alloy compacts subjected to solution treatment at (a) $850^{\circ} \mathrm{C} / 1 \mathrm{~h}$. (b) $955^{\circ} \mathrm{C} / 1 \mathrm{~h}$.

(c) $1050^{\circ} \mathrm{C} / 1 \mathrm{~h}$. (d) $1150^{\circ} \mathrm{C} / 1 \mathrm{~h}$. (e) $1250^{\circ} \mathrm{C} / 1 \mathrm{~h}$. (f) $1270^{\circ} \mathrm{C} / 1 \mathrm{~h}$. 

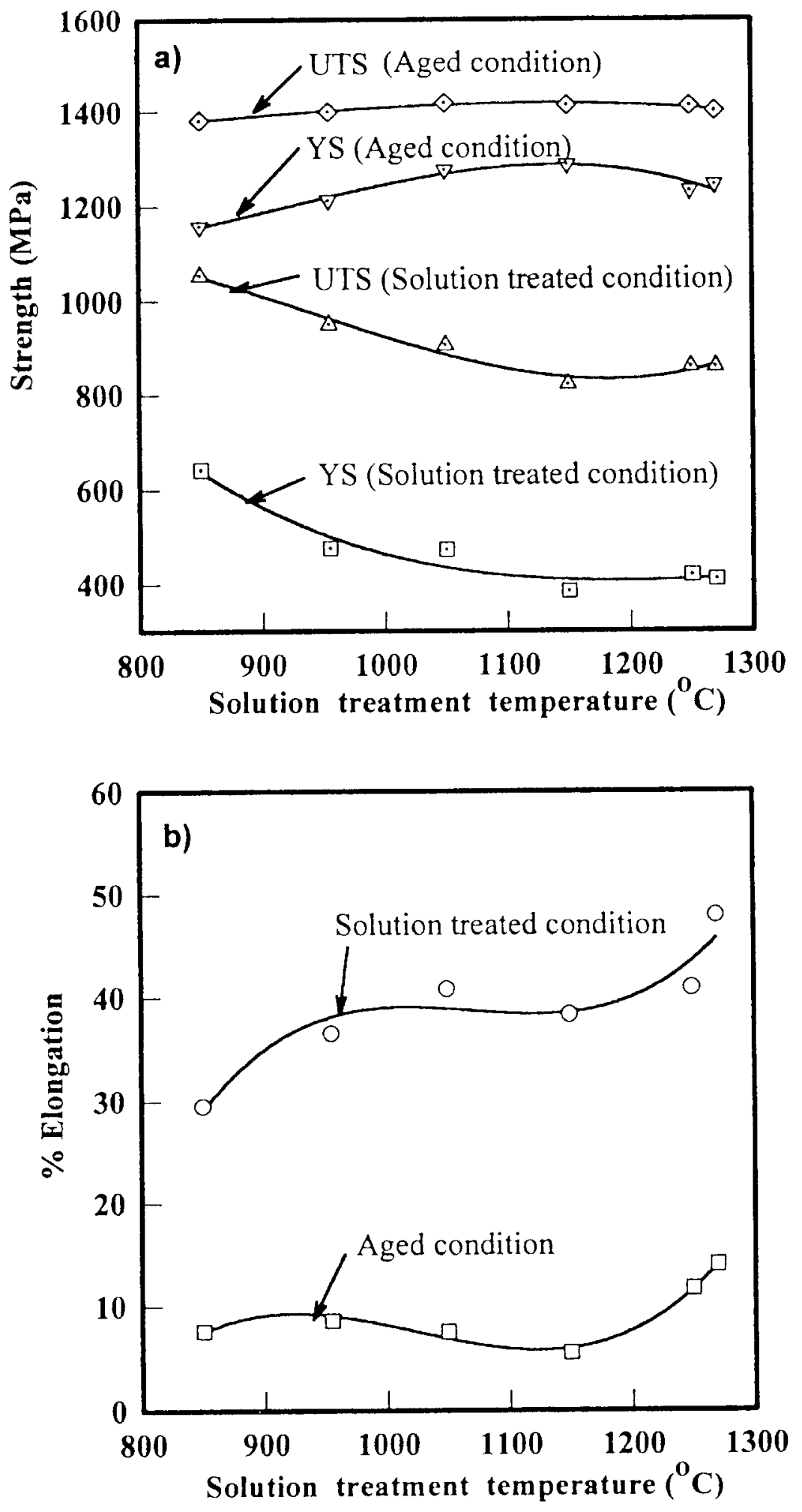

Figure 7: Effect of solution treatment temperature on room temperature tensile properties of HIP processed IN 718 alloy 


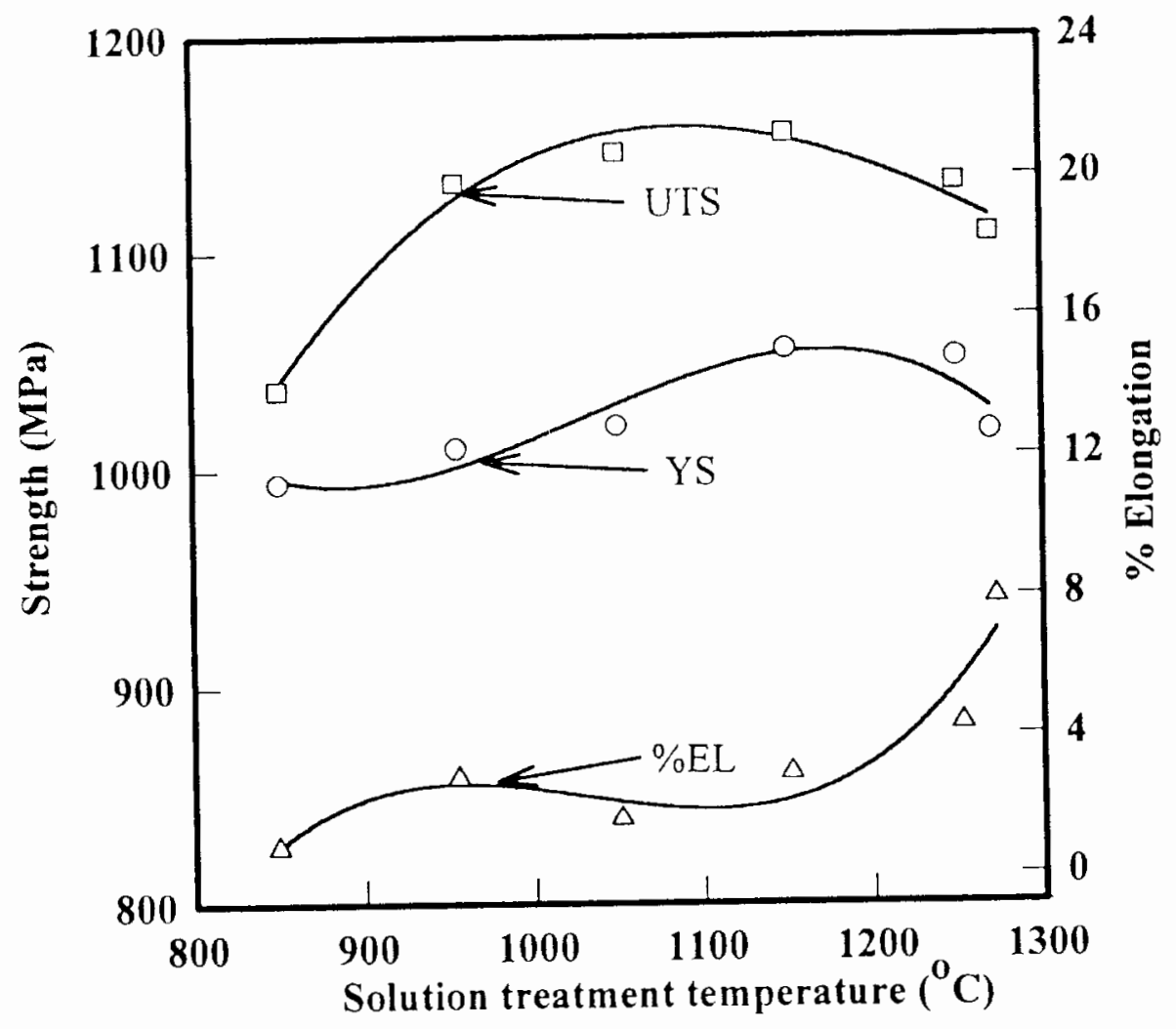

Figure 8: Tensile properties of HIP + solution treated $\left(850-1270{ }^{\circ} \mathrm{C}\right)$ and aged $\left(720^{\circ} \mathrm{C} / 8 \mathrm{~h}\right.$. FC. $620^{\circ} \mathrm{C} / 8 \mathrm{~h}$. /AC.) IN 718 samples tested at $650{ }^{\circ} \mathrm{C}$.

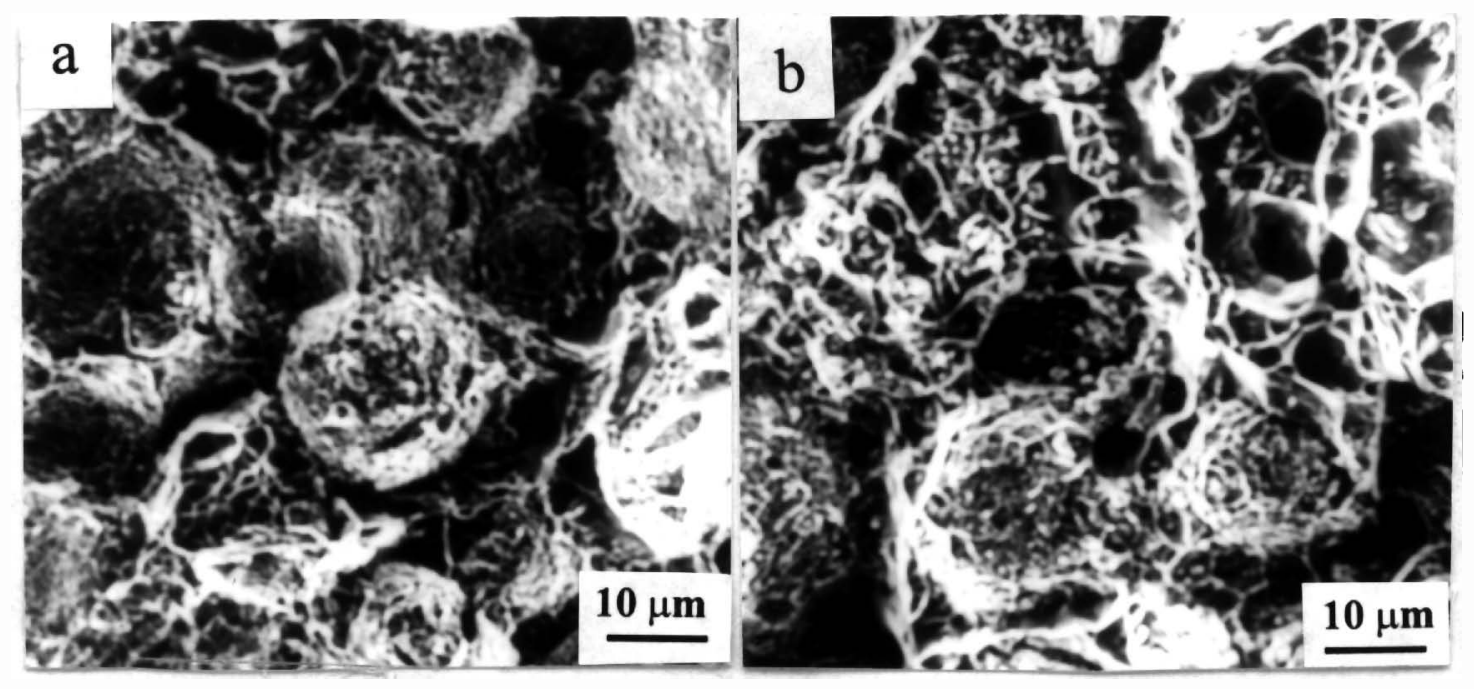

Figure 9: Fractographs of HIPed IN 718 alloy solution treated at $1270{ }^{\circ} \mathrm{C} / 1 \mathrm{~h}$. and aged at $720^{\circ} \mathrm{C} / 8 \mathrm{~h}$. FC. $620^{\circ} \mathrm{C} / 8 \mathrm{~h}$. $/ \mathrm{AC}$.

(a) Tensile tested at room temperature (b) Tensile tested at $650^{\circ} \mathrm{C}$. 
The room temperature tensile properties of solution treated compacts show lowering of strength with increasing solution treatment temperature (Fig.7.a), due to the dissolution of major strengthening phases. The tensile ductility, on the other hand, shows an improvement with increasing solution treatment temperature and attains a maximum value at $1270^{\circ} \mathrm{C}$, due to disruption of particle boundary films and enhanced bonding between the particles. The fractography of solution treated compacts over a range of temperature showed nearly similar features, conforming to ductile type of fracture. However, at a solution treatment temperature of $1270^{\circ} \mathrm{C}$, more areas with fine dimples leading to higher ductility were observed.

The room temperature tensile properties of the compacts after aging $\left(720^{\circ} \mathrm{C} / 8 \mathrm{~h}\right.$. FC. to $620^{\circ} \mathrm{C} / 8 \mathrm{~h}$. $/ \mathrm{AC}$.) show almost identical values of tensile strength, while the yield strength shows a marginal increase and attains a maximum value around $1150^{\circ} \mathrm{C} \mathrm{(Fig.7.a).} \mathrm{This} \mathrm{could}$ be due to complete dissolution of $\delta-\mathrm{Ni}_{3} \mathrm{Nb}$ phase setting free additional $\mathrm{Nb}$, to facilitate formation of $\gamma$ " during ageing treatment, thereby increasing the volume fraction of strengthening phase in the matrix. The ductility values were however low $(6.5 \pm 1.0 \%)$. Improvement of ductility (by a factor of about 2) was observed at a solution treatment temperature of $1270{ }^{\circ} \mathrm{C}$ as compared to that of at $1150^{\circ} \mathrm{C}$. The tensile properties of compacts tested at $650^{\circ} \mathrm{C}$ (Fig.8) show that the strength attains a maximum value in the range of $1100-$ $1150^{\circ} \mathrm{C}$, however, the corresponding ductility is low. A considerable improvement in ductility was observed at a solution treatment temperature of $1270{ }^{\circ} \mathrm{C}$ due to the microstructural changes, discussed earlier. The fractograph of the aged sample (corresponding to solution treatment at $1270{ }^{\circ} \mathrm{C}$ ) tensile tested at room temperature shows particle boundaries and fine dimples within the particles (Fig.9.a), suggesting that crack path along the particle boundaries and void formation near the matrix-precipitate interface. The sample tested at $650{ }^{\circ} \mathrm{C}$ shows more area of dimple rupture with a few particle boundaries (Fig.9.b), suggesting that there is definite improvement in ductility, though it was not as high as that of wrought material.

\section{Conclusions}

1. HIP processed IN 718 alloy showed considerable improvement in strength but drastic decrease in ductility when subjected to standard heat treatment schedule. The poor ductility was attributed to the presence of prior particle boundaries.

2. Considerable improvement in ductility was achieved when solution treatment was performed at a temperature of $1270{ }^{\circ} \mathrm{C}$, because it leads to dissolution of PPB precipitates, disruption of oxide film at the particle boundaries and enhanced bonding between the particles.

\section{Acknowledgements}

The authors are thankful to Dr. D. Banerjee, Director DMRL for his constant encouragement to carry out this study and granting permission to publish this work. Thanks are also due to the members of Powder processing group, Mechanical engineering group, Metallography, SEM, TEM and Mechanical testing groups for their technical help. 


\section{References}

1. D. Fournier and A. Pineau, "Low Cycle Fatigue Behaviour of Inconel 718 at $298 \mathrm{~K}$ and 823 K", Metall. Trans., 8A, (1977), 1095 - 1105.

2. R. P. Jewett and J. A. Halchak, "The Use of Alloy 718 in the Space Shuttle Main Engine", Superalloys 718, 625 and Various Derivatives, Ed., E. A. Loria. TMS, Warrendale, PA, (1991), $749-760$.

3. S .T. Wlodek and R. D. Field, "Freckles in Cast and Wrought Products", Superalloys 718, 625, 706 and Various Derivatives, Ed., E.A. Loria, TMS, Warrendale, PA, (1994), $167-176$.

4. L. A. Jackman, et al.," White Spots in Superalloys", Superalloys 718, 625, 706 and Various Derivatives, Ed., E. A Loria, TMS, Warrendale, PA, (1994), 153-166.

5. J. F. Radavich and D. J. Meyers, “ Thermomechanical Processing of P/M Alloy 718, Proceedings of Fifth International Symposium on Superalloys, Eds., Maurice et al., TMS, Pennsylvania, USA, October 7 - 11 (1984), 347 - 356.

6. H. F. Merrick, "Effect of Heat Treatment on the Structure and Properties of Extruded P/M alloy 718', Metall. Trans, Vol.7A, (1976), 505-514.

7. N. Panton, T. Carbal, K. Bowen, T. Tom, "Spray cast - $\mathrm{X}^{(\mathrm{R})} \mathrm{IN} 718$ Processing Benefits', Superalloys 718, 625,706 and Various Derivatives, Ed., E. A. Loria, TMS, Warrendale, PA, (1997), 1 - 16.

8. J. J. Valencia, T. M. Cabe, K. Hens, J. O. Hensen and A. Bose, "Microstructure and Mechanical properties of Inconel 625 and 718 alloys Processed by Powder Injection Moulding', Superalloys 718, 626, 706 and Various Derivatives, Ed., E. A. Loria, TMS, Warrendale, PA, (1994), 935-945.

9. H.V. Atkinson and B.A. Riknson, Hot Isostatic Processing (New Yark: Philadelphia, Adam Hilger, Bristol, (1991).

10. L. Li, S.Z.Yang, and J.X, Qiang, "Microstructure and Properties of HIP, HIP plus Forged and Extruded P/M Superalloys FGH95", PM Aerospace Materials, International Conference, Berne, Switzerland, Vol.1, (1984), 1-15.

11. Metals Handbook, Vol.7, $9^{\text {th }}$ edn. (Metals Park OH: American Society for Metals, 1984) 209-290.

12. G. Appa Rao, S. Balasubramaniam and Mahendra Kumar, "A Study on Processing of Inconel 718 Superalloy through P/M (HIP) Route", (Report DMRL/TR-97220, Defence Metallurgical Research Laboratory, 1997).

13. R. Tamburaj, W. Wallace, Y. N. chary and T. L. Prakash, "Influence of Processing Variables on Prior Particle Boundary Precipitation and Mechanical Behaviour in PM Superalloy APK1", Powder Metallurgy, Vol.27, No.3 (1984), 169- 180.

14. Armida Oradei-Basile, and J. F. Radavich, A Current T - T - T Diagram for Wrought Alloy 718", Superalloys 718, 625, and Various Derivatives, Ed., E. A. Loria, TMS, Warrendale, PA, 1991), $325-335$.

15. C. Marquez, G. L. Esperance and A. K. Koul, " Prior Particle Boundary precipitation in Ni-based Superalloys", The International Journal of Powder Metallurgy, Vol.25, No.4, (1989) 301-308.

16. Donald R. Muzyka, "The Metallurgy of Nickel - Iron Alloys", The Superalloys, Ed ., C. T. Sims and W. C. Hagel, John Wiley, New York, (1972) $113-143$.

17. A. K. Koul, P.Au, N.Bellinger, R.Tamburaj, W. Wallace, and J. P. Immarigeon, "Development of a Damage Tolerant Microstructure for Inconel 718 Turbine Disc Material", Sixth International Symposium on Superalloys, Eds., D. N. Duhl et al., TMS, Pennsylvania, September, (1998), 3 - 12.

18. W. Wallace, W. Wiebe, W. P. Whelan, R.V. Dainty and T. Terada, "The Effect of Grain-Boundary Structure on the Tensile Fracture Behavior of Hot-Isostatically Pressed 713 LC Alloy Compacts", Powder Metallurgy, Vol. (16), No.32, (1973), 416-436. 